\title{
Kurdish EFL Learners' Perceptions towards Written Corrective Feedback and Its Types: An Investigative Study
}

\author{
Rizgar Qasim Mahmood \\ English Department, College of Education \\ Salahaddin UniversityErbil, Iraq \\ Email: Rizgar.mahmood@su.edu.krd
}

Received: 8/10/2021 Accepted: 10/12/2021 Published: 12/15/2021

\section{Abstract}

Written Corrective Feedback has been one of the most controversial topics (Waller, 2015), and it has been researched extensively. Still, the lack of research among Kurdish EFL learners made it necessary to conduct the current research. This study focuses on investigating learners' perceptions of written corrective feedback and its types. It attempts to answer what the Kurdish EFL learners' perceptions of written corrective feedback are, and what types of written corrective feedback among Kurdish Learners are preferred. Answering these questions is significant as the results can be used by both teachers and learners to improve learners' writing accuracy. A survey questionnaire was distributed to collect data. After analyzing data, the results reveal that most Kurdish EFL participants were not fully aware of WCF and its effectiveness as a learning tool. However, they still expected their writing teachers to provide them with WCF in writing tasks. Also, the results indicate that Kurdish EFL learners preferred two types of WCF: explicit and implicit WCF. Hence, the results have many pedagogical implications for writing teachers and learners. Firstly, it shows how EFL learners from other countries and contexts perceive WCF, and secondly, results encourage writing teachers to give more attention and value to WCF.

Keywords: Kurdish EFL Learners, learner's perceptions, written corrective feedback, foreign context, learning tools, university students

Cite as: Mahmood, R. Q. (2021). Kurdish EFL Learners' Perceptions towards Written Corrective Feedback and Its Types: An Investigative Study. Arab World English Journal, 12 (4) 103- 117. DOI: https://dx.doi.org/10.24093/awej/vol12no4.7 


\section{Introduction}

Learning any language can be challenging because learners have to attempt to master the four major micro-skills (i.e., speaking, listening, reading, and writing). Thus, both teachers and learners must give adequate attention and importance to all the language skills. Research has shown that one of the most challenging and complicated skills of a target language is writing skills (Alimohammadi \& Nejadansari, 2014; Farag, 2014). Writing teachers have been trying to utilize effective strategies to improve their students' writing skills and accuracy. Hence, one of these strategies is the provision of Written Corrective Feedback (WCF). Researchers have defined WCF in a variety of ways. For instance, Bitchener and Storch (2016) state that "written $\mathrm{CF}$ is a written response to a linguistic error [and it] seeks to either correct the incorrect usage or provide information about [the error]" (p. 1). Lightbown and Spada (2013) defined Corrective Feedback (CF) as "an indication to the learners that his or her use of the target language is incorrect" (p. 216). Furthermore, Li (2010) described CF as in Second Language Acquisition (SLA) as “the responses to a learner's non-target-like L2 production” (p. 309).

Even though results from previous studies have shown that teachers have been trying to find practical tools to help their learners improve in writing classes, EFL/ESL learners are still facing many problems doing writing tasks (Styati \& Rodliyah, 2021). A strategy that always has a unique position in the field of SLA is WCF because previous research has shown that WCF can enhance learners' writing skills and accuracy as learners have been facing difficulties in mastering writing skills (Bitchener, Young, \& Cameron, 2005; Ellis, Sheen, Murakami, \& Takashima, 2008).

WCF has been one of the most debatable and controversial topics in the field of SLA and among writing teachers in the last four decades. Yet, the usefulness of WCF cannot be nullified, nor can it be verified. In this regard, researchers have been divided into two groups: those in favor of WCF, and the other group is against the provision of WCF. For example, the results of a study by Bitchener and Knoch (2010) show that WCF plays a vital role in improving learners' writing accuracy. Furthermore, Ferris (1995) has evidenced that learners appreciated their teachers' feedback, and they believed that WCF is useful in helping learners to improve their writing skills. Truscott (1996), on the other hand, states that "Grammar correction has no place in writing courses and should be abandoned" (p. 1). In addition to that, several studies by Cohen and Robbins (1976) and Krashen (1992) have concluded that correcting learners' grammar errors are ineffective for two reasons: first, learners may not check the feedback they receive, and second, if they do, they cannot point out to a comment that helps them correct the error identified. As discussed in the introduction, WCF has been the attention point of both teachers and researchers in the field of SLA, and thus, it is necessary to investigate and conduct more research on this topic. Hence, the current study was gushed out from the ocean of WCF, which cannot be verified by the available literature; therefore, more and more research needs to be conducted to investigate this issue from different contexts and with diverse ESL/EFL learners.

Although much research has been conducted to explore WCF in ESL/EFL contexts, very little research has been undertaken among Kurdish EFL learners. Therefore, to provide more effective second language (L2) teaching writing classes, it is crucial to understand learners' perceptions of WCF and its types. Hence, the current research aims at addressing the following questions: 
1. What are the perceptions of Kurdish EFL learners towards WCF?

2. What are the perceptions of Kurdish EFL learners of WCF types?

3. Do Kurdish EFL learners use/see WCF as a learning tool to improve their writing accuracy?

\section{Literature Review}

This research examined the perceptions of Kurdish EFL learners of WCF and its types. It also investigated what EFL learners have to say on writing skills and receiving CF from their writing teachers.

Written corrective feedback is widely used as a learning tool to improve and develop Second Language (L2) writing skills (Boggs, 2019; Cheng \& Zhang, 2021; Hyland \& Hyland, 2006; Lee, 2019). On that basis, the importance and the value of WCF have been examined continuously by researchers (Atmaca, 2016). In the studies that have been done, it is still debatable what roles WCF plays in language classrooms. In the literature section, the types, the usefulness, and the results of previous studies were reviewed and discussed in more detail.

\section{Types of Written Corrective Feedback (WCF)}

In writing classes, teachers tend to give different types of WCF, and several kinds of WCF have been studied and investigated, such as direct, indirect, comprehensive, and selective WCF.

\section{Direct versus Indirect $W C F$}

Teachers and researchers have been asking the question that whether direct or indirect WCF is more effective for learners. In that regard, both direct and indirect WCF has been defined differently. For instance, Ferris (2003) explained direct corrective feedback and stated that when the teachers provide the correct linguistic form or the correct language structure to the learners' linguistic error is called direct corrective feedback. The provided correction might be related to grammar rules, spelling mistakes, unnecessary punctuation marks, using unappropriated words or phrases.

On the contrary, indirect corrective feedback is when the teacher indicates where the learners have made a mistake without correcting or giving them the correct form of the error (Ferris, 2003). In this case, the teacher might use some symbols or indications to draw the learners' attention to realize that they have made an error in their writing work. Teachers use several common symbols and codes for giving indirect CF, such as (VT: verb tense, Sp. Spelling, WW: wrong word) (Ellis, 2008).

\section{Comprehensive versus Selective WCF}

Another type of CF is called comprehensive WCF. For this type, the teacher provides corrective feedback to all the errors that the student has made. This type of feedback has been implemented a lot among ESL/EFL teachers because they think that students have to avoid making mistakes, and giving feedback has to be a tool for their writing skills improvement (Ferris, Hyland, \& Hyland., 2006; Lee, 2004; 2008). This type of corrective feedback is seen as a challenging task for the teacher because they have to mark all the learners' writing errors, and the problem is more difficult if there are too many learners in one class (Ferris, 2011). In 
contrast, selective WCF is also called focused. As the name denotes that meaning, the teacher focuses on certain or selected errors and gives corrective feedback to the learners' writing task. This type of feedback has been researched a lot, and it has been seen as an effective strategy to improve learners' writing accuracy (Bitchener, 2008; Ellis et al., 2008; Sheen, Wright, \& Moldawa, 2009).

\section{ESL/EFL Learners' Perceptions of WCF}

Reviewing the existing literature on WCF, two worth noticing viewpoints have been detected among WCF researchers. First, a group of researchers (e.g., Abdollahifam, 2014; Bitchener, 2012; Bitchener \& Knoch, 2010; Beuningen, Jong, \& Kuiken, 2011; Chung, 2015; Ellis et al., 2008; Ferris \& Roberts, 2001; Kim \& Emeliyanova, 2019; Lee, 2019) believed that WCF plays an essential role in improving learners' writing skills and accuracy. For instance, Bitchener (2012) stated that "CF is able to effect improved control over the targeted struct" (p.856). But this research focuses on the perceptions of learners towards WCF. Another group of researchers (e.g., Liu, 2008; Semke, 1984; Truscott \& Hsu, 2008) are against providing WCF. These researchers believed that WCF is more harmful than helping improve learners' writing accuracy. Thus, reviewing the available literature on this matter is crucial.

To a great extent, writing instructors give WCF to their learners to show them what kind of errors they made, and how to correct them. It is crucial to know learners' perceptions about their teachers' feedback because understanding them can help teachers give more effective types of WCF. Studies that have been conducted on learners' perceptions conclude that L2 learners realize the importance of the feedback they receive - that it is one of their ways to improve their writing abilities - and they like their teachers' feedback (Abdollahifama, 2014). Learners in EFL/ESL contexts expect some kind of corrective feedback from their teachers. For instance, Atmaca (2016) found that Turkish EFL learners indicated that WCF is a learning tool that improves their writing abilities. Teachers should help learners to find their errors because if the teacher does not mark any mistakes, the learners think they did not make any errors. Furthermore, Leki (1991) found that learners expect their writing teachers to correct all the errors in their writing assignments. In contrast, some other learners mentioned that the teachers should not interfere with errors; instead, they have to guide the learners in finding the errors they make. Those learners who preferred only guidance in error discovery believed that this way helps them to be more independent and more autonomous when they correct their errors (Atmaca, 2016). A study by Mackey et al. (2007) about the learners' perceptions concluded that learners understand the importance of WCF, and they believed that teachers' intervention helps learners to improve their writing accuracy, especially the learners' lexical and grammatical accuracy. Both ESL/ EFL learners showed a strong preference for their teachers' comments (Hedgcock \& Lefkowitz, 1994). Furthermore, in a study, $77 \%$ of the learners agreed that when they write an assignment, they try to write to the best of their abilities so that the feedback is directed to their most advanced level of writing (Diab, 2005).

The English language has been one of the main subjects at various educational institutions in Middle Eastern countries such as Iran or Iraq. Still, there has not been much research about EFL learners in these countries, especially in Iraq. The perceptions of learners to the teacher's feedback are unknown. For example, the only study that the researcher could identify was Rahimi's (2010) on Iranian learners' preferences for receiving error feedback and 
their beliefs about teachers' strategies in giving feedback. The study showed that $54 \%$ of the participants reported that WCF would help them be more proficient in their writing skills. In addition to the participants' perceptions of WCF, they also noted that learners have varying preferences towards the types of WCF from their teachers. Some learners would prefer explicit feedback because they consider it very challenging to find their errors and correct them.

To summarize, WCF has been examined in different teaching contexts, such as EFL and ESL classes. Researchers have been divided into two groups. Some researchers, such as Truscott (1996), claimed that WCF does not help learners improve their writing abilities, even warning that it might be harmful to them. In contrast, other researchers like Ferris and Roberts (2001) argued that WCF is a valuable tool for learning development. Despite two opposing claims about WCF and its values, a lot more researchers have been attracted to the subject matter from different countries with different English language learners, and a lot of research has been addressed this issue. However, the researcher could not identify any studies about the perceptions of Kurdish EFL learners of WCF and how they react towards its types regarding its effectiveness in developing writing ability.

Consequently, it can be concluded that more study was/is still necessary to be conducted with learners from different contexts. Therefore, the current research has been carried out among Kurdish EFL learners in Iraqi Kurdistan. In this context (i.e., Iraqi Kurdistan), learners have been taught English for more than four decades. They received their bachelor's degree in the English language, yet, not much has been written on WCF among Kurdish EFL learners. Therefore, the value of this research is countless as it is one of the first studies that has been conducted with Kurdish EFL students, and it is important to investigate the effectiveness of WCF in different ESL/EFL contexts to validate the existing results of other studies.

\section{Methods}

To achieve the purpose of the current study, the researcher administered a survey questionnaire to collect data. The primary reason to adopt this method was to understand and investigate the participants' perceptions of WCF and its types. The researcher believed that using a survey questionnaire could achieve the goal because the participants' responded to the survey anonymously.

\section{Participants and Context}

The context where this research was conducted was at Salahaddin University, College of Education, English Department. English has been taught for more than two decades (i.e., since 1998) at this department as a foreign language. Learners at this university study the English language for four years to obtain their bachelor's degree. The main reason to choose this context is that writing courses are one of the main core courses at the curriculum, and not much research has been done in this context with Kurdish EFL learners.

The participants for this study were chosen from two different contexts: ten college ESL learners at California State University, Northridge-USA, and 50 Kurdish learners in Iraqi Kurdistan at the Salahaddin University, College of Education, English Department. The researcher used a random sampling method to choose the participants. Overall, 60 learners participated in a survey questionnaire to collect data for this study. The learners (32 females and 
28 males) were learning English as a second/foreign language. They were from different backgrounds and nationalities. Their proficiency level was varied between intermediate to lowadvanced. The learners' ages ranged from 18 to 25 years old. The mean age was 20 years old. The participants participated in this study willingly. The Kurdish EFL participants were chosen from two different years: the first year and the second year (i.e., the undergraduate study is in four years). There were two main reasons for this type of selection. First, learners from the first year are fresh to the university environment, and they take basic writing courses to learn how to write English sentences to paragraphs academically. Thus, it is crucial to investigate how much first-year learners know and use WCF to improve their writing skills. On the other hand, learners in the second year have already learned the introductory of writing skills, and the second year is when they have to learn the other complex structures of writing tasks.

\section{Research Instruments}

A survey questionnaire was used to collect data for this study. It had two parts: the first part consisted of ten statements (Appendix A), and both Kurdish EFL and ESL participants rated the statements, and the second part of the questionnaire (Appendix B), which also consisted of ten additional statements, mainly focused on the types of WCF and was rated only by the Kurdish EFL learners. The primary focus of the statements was on the learners' perceptions toward WCF and its types. The questionnaire statements used in this study were adapted from previous studies by these researchers (Atmaca, 2016; Diab, 2005; Ferris \& Roberts, 2001; Waller $\&$ Papi, 2017). Some of the statements were modified and adapted for this study to be more appropriate for the participants. For both parts of the questionnaire, a five-point Likert scale ranging from 1 (never) to 5 (always) was used for all. Participants were asked to rate from 1 to 5 on the survey questionnaire.

\section{Data Collection}

As mentioned before, the participants were in the first and second year of their undergraduate studies, and they had been studying English and taking writing classes for one/two years. For the data collection process, the participants were given the survey. They had been given enough time to read and complete the survey carefully to collect reliable and valid data. After completing the survey, the collected data were entered and prepared to be analyzed.

To analyze the collected data, Descriptive statistics were performed using SPSS version 21.0. The reason for performing descriptive statistics is because the research questions can be investigated and analyzed using this type of performance.

\section{Findings}

After data analysis and based on the items in the survey questionnaire, three main constructs were illustrated and extracted from the statements in the survey: 1) Reactions to WCF, 2) Understanding of WCF as a Learning Tool, and 3) Digestion of WCF.

\section{Reactions to $W C F$}

In this construct, the learners' reactions towards WCF have been investigated. As presented in Table one, the first section included three questionnaire statements (see Appendix A) highlighting learners' reactions to WCF, hence named Reactions to WCF. After the collected data was analyzed, values of the mean and standard deviation scores were used to provide the results. Based on the results in Table one, Kurdish EFL learners have different reactions to WCF. 
The EFL learners' varying responses (i.e., dispersion within the group) are drawn from greater SD values (SD: 1.25). Lower mean values simply indicate the group's (EFL learners) less active reaction to WCF than the other group (ESL learners). In contrast, the ESL learners showed more consistent responses to these statements, and more positively reacted to WCF, and this can be calculated based on the high mean score of (4.50) out of (5.00) with the lowest standard deviation of (0.32) for statements seven (see Appendix A). The difference between the mean scores indicates that Kurdish EFL learners do not have a clear understanding of why they receive WCF from their teachers. The reason might be that neither all EFL teachers provide WCF nor are all learners aware of the importance of WCF to improve their writing abilities (Farag, 2014). Therefore, it can be drawn from the results that Kurdish EFL learners have not been taught about the usefulness of WCF, and some of them might not have heard what WCF is from their teachers.

Table 1. Descriptive statistics of Kurdish EFL and ESL participants' responses to the questionnaire statements

\begin{tabular}{lll}
\hline Reactions to WCF & Kurdish EFL Learners & ESL Learners \\
\hline Statement & Mean (SD) & Mean (SD) \\
2 & $3.30(0.82)$ & $4.50(0.71)$ \\
6 & $2.30(1.25)$ & $1.30(0.67)$ \\
7 & $1.80(0.92)$ & $1.10(0.32)$ \\
Understanding of WCF as a learning & Kurdish EFL Learners & ESL Learners \\
tool & Mean (SD) & Mean (SD) \\
Statement & $4.00(1.05)$ & $5.00(0.00)$ \\
1 & $4.10(0.88)$ & $4.70(0.67)$ \\
3 & $2.40(1.35)$ & $1.70(1.25)$ \\
8 & $2.90(1.52)$ & $1.80(1.32)$ \\
10 & Kurdish EFL Learners & ESL Learners \\
Digestion of feedback & Mean (SD) & Mean (SD) \\
Statement & $2.30(1.06)$ & $1.50(0.53)$ \\
5 & $4.20(0.92)$ & $4.40(0.84)$ \\
9 & &
\end{tabular}

\section{Understanding WCF as a Learning Tool}

The second section in Table one included four questionnaire statements highlighting learners' understanding of WCF, hence named Understanding WCF as a Learning Tool. This construct has been extracted from the survey questionnaire items to gain a better understanding of how Kurdish EFL learners understand WCF, and it investigates if Kurdish EFL learners know much about WCF as a learning tool or not. In these statements (see Appendix A), the participants were asked to rate if they used WCF to improve their writing abilities and avoid making the same errors. It is evident from the difference in the mean values of both EFL (4.10) and ESL learners (4.70) that ESL learners found WCF as a more powerful learning tool. However, learners in both contexts used WCF to improve their writing skills, but Kurdish EFL learners showed less consistent responses to the statements, and this result is based on different $\mathrm{SD}$ values such as high values of (1.05) to (1.52). On the other hand, the ESL learner participants had a better understanding of WCF as a learning tool, with their lower SD values of (0.00) to (1.32) showing positive reflection and consistent responses to the questionnaire statements. 
These results support the results of previous research (Faraj, 2015). In her study with Kurdish EFL learners, she found that only $48 \%$ of learners can write appropriate vocabulary with correct spelling and word forms to produce effective written work without WCF from their teachers.

\section{Digestion of $W C F$}

Finally, the researcher has attempted to investigate either Kurdish EFL learners benefit and accept their teachers' WCF or not. In this regard, the third construct has been extracted from two questionnaire statements that highlighted how both EFL and ESL learners digest WCF. Both groups of participants were asked to rate $(1=$ Never $)$ and $(5=$ Always $)$ for each statement. The statements in the questionnaire were "I like when my teacher only writes a grade and does not comment on my paper"; "When I do not understand my teacher's comments, I talk to them." The results show a slight difference among EFL and ESL learners of how well they digest WCF. For example, for statement nine (see Appendix A) in Table one, both the experimental and control groups scored similar high mean scores of $(M=4.20)$ for $E F L$ learners, and $(M=4.40)$ for $E S L$ learners with a very low standard deviation score of less than $(\mathrm{SD}=1.00)$. Surprisingly, there was not a single ESL learner that would say they always liked to see the assignment grade by itself on the paper without any feedback on statement five. Still, a few Kurdish EFL learners rated in favor of this statement which says, "I like when my teacher only writes a grade and not comment on my paper," and this difference clearly can be observed when the mean scores of both EFL and ESL participants are being compared, which are $(\mathrm{M}=2.30)$ and $(\mathrm{M}=1.50)$ for both group learners respectively.

\section{Preferred Types of WCF by Kurdish EFL Learners}

As reviewed in the previous sections, different types of WCF have been investigated and utilized by both teachers and researchers. In this section, the researcher has attempted to understand and explore what types of WCF are preferred among Kurdish EFL learners, and this section has been formed based on one of the main research questions. To examine one of the main research questions (i.e., what type of WCF Kurdish EFL learners prefer?), the Kurdish EFL participants rated ten additional statements which targeted the preferred types (i.e., explicit or implicit) of WCF from the perspective of Kurdish learners (see Appendix B). The collected data has been analyzed in Table two as the following:

Table two consists of two main sections: the first section presents the mean scores and standard deviations toward explicit WCF (i.e., correcting all vs. selectively). The participants were asked to rate on the Likert Scale (i.e., $1=$ Never to $5=$ Always) how much they agree or disagree with each statement. For example, some of the statements in the first section of the survey were "The teacher should mark and correct all errors because it is useful to learn the correct items"; "The teacher should comment on and correct my vocabulary, grammatical errors, and sentence structures"; "The teacher should underline the error and correct it."

Table 2. Descriptive statistics of Kurdish EFL participants' responses to 10 additional questionnaire statements

\begin{tabular}{ll}
\hline Explicit WCF & Kurdish EFL Learners \\
\hline Statement & Mean (SD) \\
1 & $2.70(1.06)$ \\
3 & $2.70(0.82)$ \\
4 & $2.30(1.42)$ \\
\hline
\end{tabular}




\begin{tabular}{ll}
\hline 8 & $2.80(0.63)$ \\
Implicit $W C F$ & Kurdish EFL Learners \\
Statement & Mean (SD) \\
2 & $3.60(0.70)$ \\
5 & $2.70(0.95)$ \\
6 & $2.10(1.45)$ \\
7 & $3.60(0.70)$ \\
9 & $4.30(0.48)$ \\
10 & $3.80(0.79)$ \\
\hline
\end{tabular}

Based on the analyzed data, surprisingly, participants scored differently, and they were not very consistent whether they preferred explicit WCF or implicit WCF. This result is drawn from the different scores of mean values and standard deviations. For instance, all the statements in the first part of Table two targeted explicit feedback specifically statement three and eight. For example, the lowest mean score is $(\mathrm{M}=2.70)$ for statement three, "The teacher should comment on and correct my vocabulary, grammatical errors, and sentence structures," and the highest mean value was $(M=2.80)$ for statement eight (i.e., The teacher should underline the error and correct it) with a standard deviation of ( $\mathrm{SD}=0.63)$. In addition, the statements in the first section of Table two also ask the learners to show their preferences about how comprehensive teachers have to correct the learners' errors. The results indicate that Kurdish learners preferred that selective errors have to be corrected by their teachers (i.e., vocabulary, grammatical errors, and sentence structures). This conclusion is based on the low SD value of (0.82) for statement three (i.e., The teacher should comment on and correct my vocabulary, grammatical errors, and sentence structures), and ( $\mathrm{SD}=1.06)$ for statement one (The teacher should mark and correct all errors because it is useful to learn the correct items).

On the other hand, the second section of Table two shows how much Kurdish EFL learners preferred implicit WCF. In these statements, learners were asked to rate their perceptions whether they agree or disagree with these statements. For example, some of the statements were "The teacher has to mark all significant errors but not minor ones"; "The teacher should show only where the error is with no correction"; "The teacher should mark only errors that interfere with communicating ideas." Once again, a very high mean score of $(\mathrm{M}=4.30)$ shows a strong agreement that Kurdish EFL learners profoundly believed that implicit WCF could help them improve their errors, and they did not like their teachers' intervention to give WCF for every error they made.

The above findings show that individual preferences for the types of WCF among both EFL and ESL learners exist in different contexts and countries. Thus, these results confirm the findings of some previous studies (Bitchener \& Knoch, 2010; Chandler, 2003; Chung, 2015). In these studies, the results show that implicit WCF helps learners correct their errors by themselves. One of the significant findings of this study is that the Kurdish EFL learners have shown variances in their perceptions and beliefs towards WCF and its types. The evidence is the inconsistent distributions of the mean and standard deviation values in Table one and Table two. To utilize WCF more effectively, individual differences among the learners have to be taken into consideration. Teachers have to dedicate adequate time to provide WCF. Also, it can be noticed that Kurdish EFL learners are similar to other learners in benefitting from WCF, and they expect and appreciate error feedback from their teachers. To find out why Kurdish EFL learners were 
not consistent about the types of WCF (i.e., explicit or implicit), the reason might be the lack of knowledge on WCF and its types among Kurdish EFL learners, and this is also related to the teachers who teach writing classes in the Kurdish EFL context.

\section{Discussion}

The findings suggest that written corrective feedback the perceptions of ESL learners are different than EFL learners in terms of using it as one of the effective learning tools. Although EFL learners showed the value of WCF, they were not consistent in their perceptions towards it. Still, it is worth mentioning that both groups of participants from ESL/EFL contexts expected to receive $\mathrm{CF}$ from their teachers because they believed that with the provision of WCF, they would be able to improve their writing accuracy. This finding has also been confirmed with the conclusions in the study by Bitchener and Knoch (2010).

Although most writing teachers provide WCF and mark their learners' errors, some learners prefer to have only the writing task grade with no correction comments. This phenomenon was also observed among the Kurdish EFL learners in the current study. It is crucial to investigate this observation more because the purpose of giving WCF is to help learners to improve their writing abilities, not discourage them upon receiving WCF.

Regarding the types of WCF, there were a variety of perceptions. For instance, some participants preferred explicit WCF, and some others preferred implicit WCF. This was also true with the ESL learners. Based on the participants' responses, this variety of preferences was that some learners wanted to see the correct form from their teachers. These findings aligned with the conclusions of the study by Bozorgian and Yazdani (2021).

\section{Conclusion}

Although written corrective feedback has been researched extensively in both ESL/EFL contexts, yet very little research is available in a foreign context (i.e., Kurdish context). This lack of literature with Kurdish EFL learners indicates that corrective feedback is not investigated, and it is overlooked. As previous studies show that WCF has been found as an effective tool to improve learners' writing abilities and accuracy, it is necessary to examine it in a context where the English language has been taught for more than 20 years. Thus, the current study attempted to investigate Kurdish EFL learners' perceptions of WCF and its types. This study provides several insights into a sample of Kurdish university EFL learners' perceptions towards WCF as an effective learning tool. The results show that the participants were not fully aware of the usefulness of WCF for improving learners' writing accuracy. Still, on the whole, the learner participants believed that WCF is expected to be given by their teachers. Regarding utilizing WCF as a learning tool, the EFL Kurdish participants were inconsistent in their responses (SD= 1.05 to 1.52). Conversely, the ESL participants have had a better understanding of WCF as a learning tool. Another crucial finding was that Kurdish EFL learners had a variety of preferences towards the types of WCF. For instance, some participants thought that explicit WCF is more effective, and others believed that implicit WCF and the reasons were not clear; therefore, more research is needed to be conducted in that regard.

This study confirms that Kurdish EFL learners expect to receive WCF from their teachers. Thus, in the Kurdish context, writing teachers have to give more importance to this 
strategy to help their learners improve their writing accuracy. By conducting this study, it is expected that the results encourage researchers to investigate other writing issues among Kurdish EFL learners. It is also hoped that the results provide better solutions to increase the quality of education in Iraqi Kurdistan.

\section{About the author:}

Rizgar Qasim Mahmood holds MA in Linguistics/TESL from the California State University, Northridge, USA (2019). He is currently working in Iraqi Kurdistan as an assistant lecturer at Salahaddin University, Erbil. He researches in the areas of Second Language Acquisition/ Pronunciation, Teacher Education/ Teacher Cognition, Teaching English as a second/foreign language, Writing Skills and Corrective Feedback, Native and Nonnative English Teachers, Comparative Languages, L2 Motivation, Language Learning Strategies, and Classroom-based Practice. He is also a Fulbright Alumni. https://orcid.org/0000-0002-5987-8884

\section{References}

Abdollahifam, S. (2014). Investigating the Effects of Interactional Feedback on EFL Students' Writings. Procedia - Social and Behavioral Sciences, 98, 16-21. https://doi.org/10.1016/j.sbspro.2014.03.383

Alimohammadi, B., \& Nejadansari, D. (2014). Written Corrective Feedback: Focused and Unfocused. Theory and Practice in Language Studies, 4(3), 581-587. https://doi.org/10.4304/tpls.4.3.581-587

Atmaca, Ç. (2016). Contrasting perceptions of students and teachers: written corrective feedback. Journal of Language and Linguistic Studies, 12(2), 166-182.

Beuningen, C. G., Jong, N. H., \& Kuiken, F. (2011). Evidence on the Effectiveness of Comprehensive Error Correction in Second Language Writing. Language Learning, 62(1), 1-41. https://doi.org/10.1111/j.1467-9922.2011.00674.x

Bitchener, J. (2008). Evidence in support of written corrective feedback. Journal of Second Language Writing, 17(2), 102-118. https://doi.org/10.1016/j.jslw.2007.11.004

Bitchener, J. (2012). Written Corrective Feedback for L2 Development: Current Knowledge and Future Research. TESOL Quarterly, 46(4), 855-860. https://doi.org/10.1002/tesq.62

Bitchener, J., \& Knoch, U. (2010). Raising the linguistic accuracy level of advanced L2 writers with written corrective feedback. Journal of Second Language Writing, 19(4), 207-217. https://doi.org/10.1016/j.jslw.2010.10.002

Bitchener, J., \& Storch, N. (2016). Written Corrective Feedback for L2 Development. Multilingual Matters Limited.

Bitchener, J., Young, S., \& Cameron, D. (2005). The effect of different types of corrective feedback on ESL student writing. Journal of Second Language Writing, 14(3), 191-205. https://doi.org/10.1016/j.jslw.2005.08.001

Boggs, J. A. (2019). Effects of teacher-scaffolded and self-scaffolded corrective feedback compared to direct corrective feedback on grammatical accuracy in English L2 writing. Journal of Second Language Writing, 46, 100671. https://doi.org/10.1016/j.jslw.2019.100671

Bozorgian, H., \& Yazdani, A. (2021). Direct Written Corrective Feedback with Metalinguistic Explanation: Investigating Language Analytic Ability. Iranian Journal of Language Teaching Research, 9(1), 66-79. https://doi.org/10.30466/ijltr.2021.120976 
Arab World English Journal (AWEJ) Volume 12. Number 4. December 2021

Kurdish EFL Learners' Perceptions towards Written Corrective Feedback

Mahmood

Chandler, J. (2003). The efficacy of various kinds of error feedback for improvement in the accuracy and fluency of L2 student writing. Journal of Second Language Writing, 12(3), 267-296. https://doi.org/10.1016/s1060-3743(03)00038-9

Cheng, X., \& Zhang, L. J. (2021). Sustaining University English as a Foreign Language Learners' Writing Performance through Provision of Comprehensive Written Corrective Feedback. Sustainability, 13(15), 8192. https://doi.org/10.3390/su13158192

Chung, B. (2015). Written Corrective Feedback: The Perception of Korean EFL Learners. Journal of Pan-Pacific Association of Applied Linguistics, 19(2), 75-88. https://eric.ed.gov/?id=EJ1092436

Cohen, A. D., \& Robbins, M. (1976). Toward Assessing Interlanguage Performance: The Relationship Between Selected Errors, Learners' Characteristics, and Learners' Explanations. Language Learning, 26(1), 45-66. https://doi.org/10.1111/j.14671770.1976.tb00259.x

Diab, R. (2005). EFL University Students' Preferences for Error Correction and Teacher Feedback on Writing. TESL Reporter, 38, 27-51.

Ellis, R., Sheen, Y., Murakami, M., \& Takashima, H. (2008). The effects of focused and unfocused written corrective feedback in an English as a foreign language context. System, 36(3), 353-371. https://doi.org/10.1016/j.system.2008.02.001

Ellis, R. (2008). A typology of written corrective feedback types. ELT Journal, 63(2), 97-107. https://doi.org/10.1093/elt/ccn023

Faraj, A. K. (2015). Scaffolding EFL Students' Writing through the Writing Process Approach. Journal of Education and Practice, 6(13), 134-144.

Farag, L. M. (2014). An investigation of teachers' self-reported and actual written feedback practices in Egyptian ESL classes, (Unpublished Master's Thesis). The American University in Cairo, Egypt.

Ferris, D., Hyland, K., \& Hyland, F. (2006). Does error feedback help student writers? New evidence on the short- and long-term effects of written error correction. Feedback in Second Language Writing, 81-104. https://doi.org/10.1017/cbo9781139524742.007

Ferris, D. R. (1995). Student Reactions to Teacher Response in Multiple-Draft Composition Classrooms. TESOL Quarterly, 29(1), 52-53. https://doi.org/10.2307/3587804

Ferris, D. R. (2003). Response to Student Writing: Implications for Second Language Students. Routledge.

Ferris, D. R. (2011). Treatment of Error in Second Language Student Writing-(2 ${ }^{\text {nd }}$ ed.). University of Michigan Press/ELT.

Ferris, D., \& Roberts, B. (2001). Error feedback in L2 writing classes. Journal of Second Language Writing, 10(3), 161-184. https://doi.org/10.1016/s1060-3743(01)00039-x

Hedgcock, J., \& Lefkowitz, N. (1994). Feedback on feedback: Assessing learner receptivity to teacher response in L2 composing. Journal of Second Language Writing, 3(2), 141-163. https://doi.org/10.1016/1060-3743(94)90012-4

Hyland, K., \& Hyland, F. (2006). Feedback on second language students' writing. Language Teaching, 39(2), 83-101. https://doi.org/10.1017/s0261444806003399

Kim, Y., \& Emeliyanova, L. (2019). The effects of written corrective feedback on the accuracy of L2 writing: Comparing collaborative and individual revision behavior. Language Teaching Research, 25(2), 234-255. https://doi.org/10.1177/1362168819831406

Krashen, S. D. (1992). Formal Grammar Instruction. Another Educator Comments. TESOL Quarterly, 26(2), 409-411. https://doi.org/10.2307/3587020 
Arab World English Journal (AWEJ) Volume 12. Number 4. December 2021

Kurdish EFL Learners' Perceptions towards Written Corrective Feedback

Mahmood

Lee, I. (2004). Error correction in L2 secondary writing classrooms: The case of Hong Kong. Journal of Second Language Writing, 13(4), 285-312. https://doi.org/10.1016/j.jslw.2004.08.001

Lee, I. (2008). Ten mismatches between teachers' beliefs and written feedback practice. ELT Journal, 63(1), 13-22. https://doi.org/10.1093/elt/ccn010

Lee, I. (2019). Teacher written corrective feedback: Less is more. Language Teaching, 52(4), 524-536. https://doi.org/10.1017/s0261444819000247

Leki, I. (1991). The Preferences of ESL Students for Error Correction in College-Level Writing Classes. Foreign Language Annals, 24(3), 203-218. https://doi.org/10.1111/j.19449720.1991.tb00464.x

Li, S. (2010). The Effectiveness of Corrective Feedback in SLA: A Meta-Analysis. Language Learning, 60(2), 309-365. https://doi.org/10.1111/j.1467-9922.2010.00561.x

Lightbown, P., \& Spada, N. (2013). How Languages are Learned 4e (Oxford Handbooks for Language Teachers) $\left(4^{\text {th }}\right.$ ed.). Oxford University Press.

Liu, Y. (2008). The Effects of Error Feedback in Second Language Writing. Arizona Working Papers in SLA \& Teaching, 15, 65-79. Available at https://journals.uair.arizona.edu/index.php/AZSLAT/article/view/21254

Mackey, A. et al. (2007). Teachers' Intentions and Learners' Perceptions about Corrective Feedback in the L2 Classroom. Innovation in Language Learning and Teaching, 1(1), 129-152. https://doi.org/10.2167/illt047.0

Mackey, A., Al-Khalil, M., Atanassova, G., Hama, M., Logan-Terry, A., \& Nakatsukasa, K. (2007). Teachers' Intentions and Learners' Perceptions about Corrective Feedback in the L2 Classroom. Innovation in Language Learning and Teaching, 1(1), 129-152. https://doi.org/10.2167/illt047.0

Rahimi, M. (2010). Iranian EFL Students' Perceptions and Preferences for Teachers' Written Feedback: Do Students' ideas Reflect Teachers' Practice? Journal of Teaching Language Skills (JTLS), 2(2), 75-98. https://doi.org/10.22099/jtls.2012.409

Semke, H. D. (1984). Effects of the Red Pen. Foreign Language Annals, 17(3), 195-202. https://doi.org/10.1111/j.1944-9720.1984.tb01727.x

Sheen, Y., Wright, D., \& Moldawa, A. (2009). Differential effects of focused and unfocused written correction on the accurate use of grammatical forms by adult ESL learners. System, 37(4), 556-569. https://doi.org/10.1016/j.system.2009.09.002

Styati, E. W., \& Rodliyah, R. S. (2021). INVESTIGATING STUDENTS' WRITING QUALITY WITH DIFFERENT PROFICIENCY LEVELS IN INTERACTION-BASED PAIR WORKS. Indonesian Journal of Applied Linguistics, 11(1), 39-48. https://doi.org/10.17509/ijal.v11i1.34659

Truscott, J. (1996). The Case Against Grammar Correction in L2 Writing Classes. Language Learning, 46(2), 327-369. https://doi.org/10.1111/j.1467-1770.1996.tb01238.x

Truscott, J., \& Hsu, A. Y. P. (2008). Error correction, revision, and learning. Journal of Second Language Writing, 17(4), 292-305. https://doi.org/10.1016/j.jslw.2008.05.003

Waller, L. (2015). Motivation and written corrective feedback: How students' implicit theories of writing intelligence influence their writing motivation and orientation to written corrective feedback (Unpublished Master's Thesis). Michigan State University, USA. Available at https://www.semanticscholar.org/paper/Motivation-and-written-correctivefeedback\%3A-How-of-Waller/2fe1ce045914c20d85e65fd49f21fc7f09dc5a2f 
Waller, L., \& Papi, M. (2017). Motivation and feedback: How implicit theories of intelligence predict L2 writers' motivation and feedback orientation. Journal of Second Language Writing, 35, 54-65. https://doi.org/10.1016/j.jslw.2017.01.004

\section{Appendices}

Kurdish EFL Learners' Perceptions towards Written Corrective Feedback and Its Types:

\section{An Investigative Study}

I would like to ask you to help us by answering the following questions concerning foreign language learning. This survey questionnaire has been designed about 'Kurdish EFL Learners' Perceptions towards Written Corrective Feedback and Its Types: An Investigative Study" to get a better understanding of the mentioned issue. The researcher is interested in your personal opinion. Please give your answers sincerely, as only this will guarantee the success of the investigation. You have to rate the given statement based on the provided scale, which is:

Never (NV) (1), Seldom (SEL) (2), Sometimes (SMT) (3), Often (OFT), and Always (ALS) (5)

\section{Appendix A}

Kurdish EFL Learners' Perceptions towards Written Corrective Feedback

Table 3. Statements show general information and the learners' perception of WCF and indicate it as an effective learning tool

\begin{tabular}{|c|c|c|c|c|c|c|}
\hline & Items & Res & nses & & & \\
\hline No & & NV & SEL & SMT & OFT & ALS \\
\hline 1. & $\begin{array}{l}\text { I like when my teacher corrects all of my mistakes (grammar, } \\
\text { content, organization, spelling, punctuation). }\end{array}$ & 1 & 2 & 3 & 4 & 5 \\
\hline 2. & $\begin{array}{l}\text { When I get my papers back, I read all of the comments } \\
\text { carefully }\end{array}$ & 1 & 2 & 3 & 4 & 5 \\
\hline 3. & $\begin{array}{l}\text { Written corrective feedback from my teacher helps me be a } \\
\text { better writer. }\end{array}$ & 1 & 2 & 3 & 4 & 5 \\
\hline 4. & $\begin{array}{l}\text { I remember the mistakes my teacher points out to me, and I try } \\
\text { not to make them again. }\end{array}$ & 1 & 2 & 3 & 4 & 5 \\
\hline 5. & $\begin{array}{l}\text { I like when my teacher only writes a grade and does not } \\
\text { comments on my paper }\end{array}$ & 1 & 2 & 3 & 4 & 5 \\
\hline 6. & $\begin{array}{l}\text { When I do not understand my teacher's comments, I ignore } \\
\text { them. }\end{array}$ & 1 & 2 & 3 & 4 & 5 \\
\hline 7. & I do not care about receiving feedback on my papers. & 1 & 2 & 3 & 4 & 5 \\
\hline & I would like to be told only what I did right in my paper. & 1 & 2 & 3 & 4 & 5 \\
\hline & $\begin{array}{l}\text { When I do not understand my teacher's comments, I talk to } \\
\text { them. }\end{array}$ & 1 & 2 & 3 & 4 & 5 \\
\hline 10. & When I get my papers back, I only look at the grade. & 1 & 2 & 3 & 4 & 5 \\
\hline
\end{tabular}




\section{Appendix B}

Kurdish EFL Learners' Perceptions towards Preferred Types of Written Corrective Feedback

Never (NV) (1), Seldom (SEL) (2), Sometimes (SMT) (3), Often (OFT), and Always (ALS) (5)

Table 4. Statements show the types (i.e., explicit and implicit) of WCF which are given to the learners

\begin{tabular}{|c|c|c|c|c|c|}
\hline Items & \multicolumn{5}{|c|}{ Responses } \\
\hline No & NV & SEL & SMT & OFT & ALS \\
\hline $\begin{array}{l}\text { The teacher should mark and correct all errors because it is useful } \\
\text { to learn the correct items. }\end{array}$ & 1 & 2 & 3 & 4 & 5 \\
\hline 2. The teacher has to mark all significant errors but not minor ones. & 1 & 2 & 3 & 4 & 5 \\
\hline $\begin{array}{l}\text { The teacher should comment on and correct my vocabulary, } \\
\text { grammatical errors, and sentence structures. }\end{array}$ & 1 & 2 & 3 & 4 & 5 \\
\hline $\begin{array}{l}\text { The teacher should correct punctuation, capitalization, and } \\
\text { spelling errors. }\end{array}$ & 1 & 2 & 3 & 4 & 5 \\
\hline $\begin{array}{l}\text { The teacher should mark only errors that interfere with } \\
\text { communicating ideas. }\end{array}$ & 1 & 2 & 3 & 4 & 5 \\
\hline $\begin{array}{l}\text { 6. The teacher should not mark any errors; respond only to ideas and } \\
\text { content. }\end{array}$ & 1 & 2 & 3 & 4 & 5 \\
\hline $\begin{array}{l}\text { 7. The teacher should circle/underline and use a code to indicate the } \\
\text { type of error. }\end{array}$ & 1 & 2 & 3 & 4 & 5 \\
\hline 8. The teacher should underline the error and correct it. & 1 & 2 & 3 & 4 & 5 \\
\hline $\begin{array}{l}\text { 9. The teacher should show where the error is and give a clue about } \\
\text { how to correct it. }\end{array}$ & 1 & 2 & 3 & 4 & 5 \\
\hline $\begin{array}{l}\text { The teacher should show only where the error is with no } \\
\text { correction. }\end{array}$ & 1 & 2 & 3 & 4 & 5 \\
\hline
\end{tabular}

